Rafał Moska

Instytut Nafty i Gazu - Państwowy Instytut Badawczy

Sławomir Kędzior

Uniwersytet Śląski, Wydział Nauk o Ziemi

\title{
Możliwości występowania niekonwencjonalnych akumulacji gazu ziemnego w serii mułowcowej na terenie Górnośląskiego Zagłębia Węglowego
}

\begin{abstract}
W artykule przedstawiono Górnośląskie Zagłębie Węglowe (GZW) jako obszar, na którym znajdują się skały mogące potencjalnie zawierać niekonwencjonalne akumulacje gazu ziemnego. W badaniach skoncentrowano się na serii mułowcowej, której skały ze względu na optymalną frakcję oraz wysoką zawartość materii organicznej wydają się najbardziej perspektywiczne. Oceny dokonano na podstawie analizy profili litologicznych z wybranych głębokich otworów wiertniczych wykonanych na zlecenie Państwowego Instytutu Geologicznego na przełomie lat siedemdziesiątych i osiemdziesiątych XX wieku. Dodatkowo do analizy włączono profil otworu Dębieńsko-Głębokie 7, zlokalizowany w rejonie GZW, w którym notuje się największą miąższość serii mułowcowej. Na tej podstawie podjęto próbę wyznaczenia interwałów głębokościowych o znacznym udziale skał iłowcowo-mułowcowych w profilu serii mułowcowej GZW.
\end{abstract}

Słowa kluczowe: gaz z formacji łupkowych, seria mułowcowa, kopalna materia organiczna, parametry geochemiczne, Górnośląskie Zagłębie Węglowe.

\section{Possibillities of occurence of unconventional gas accumulations in mudstone series of the Upper Silesian Coal Basin (Poland)}

This article presents the Upper Silesian Coal Basin as an area of potential unconventional gas accumulations. The research is focused on the Mudstone Series which due to its optimal grain size and high organic matter content, seems to be the most promising. The evaluation was done on the basis of lithological profiles of selected deep boreholes drilled at the request of the Polish Geological Institute in the late seventies and eighties of the $\mathrm{XX}^{\text {th }}$ century. Additionally included in the analysis is the profile of the Dębieńsko-Głębokie 7 deep hole located in the region of the Upper Silesian Coal Basin, due to the greatest thickness of the Mudstone Series in this area. On this basis an attempt was made to determine the intervals of depth with a high content of claystone and mudstone rock in the Upper Silesian Coal Basin area.

Key words: shale gas, the Mudstone Series, fossil organic matter, geochemical parameters, Upper Silesian Coal Basin.

\section{Wprowadzenie}

Od kilkunastu lat w Polsce obserwuje się intensywny wzrost zainteresowania niekonwencjonalnymi złożami węglowodorów. W Górnośląskim Zagłębiu Węglowym (GZW) od lat dziewięćdziesiątych ubiegłego wieku podejmowane są próby wprowadzenia technologii wydobycia metanu z pokładów węgla [7, 9, 11, 12, 16, 32], a na obszarze basenu polskiego oraz na Lubelszczyźnie od 2010 roku trwają prace poszukiwawcze mające na celu pozyskanie gazu z formacji łupkowych [3, 19, 23, 25].

Złoża gazu ziemnego zawartego w skałach iłowcowo-mułowcowych wyróżniają się na tle innych złóż gazu tym, że skała zbiornikowa, w której gaz jest akumulowany, to jednocześnie 
skała macierzysta i uszczelniająca, co sprawia, że gaz ziemny jest generowany in situ, a jego migracja zachodzi jedynie w skali mikro lub nie zachodzi wcale [26]. Gaz z formacji łupkowych po raz pierwszy pozyskano w USA już w XIX wieku, jednak to koniec XX wieku był okresem prawdziwego rozkwitu tej gałęzi przemysłu wydobywczego. Niekonwencjonalne metody poszukiwawcze oraz rozwój nowoczesnych technologii umożliwiły wówczas pozyskiwanie gazu z łupków na szeroką skalę, czego dobrym przykładem jest basen Fort Worth w Teksasie (USA), w którym jest prowadzona eksploatacja gazu z łupków Barnett [26].

$\mathrm{W}$ ostatnich latach okresowo wzrastające ceny ropy naftowej i gazu ziemnego spowodowały znaczne zwiększenie zainteresowania pozyskiwaniem gazu ziemnego ze złóż łupkowych. Krajem, który na skalę przemysłową wdrożył pozyskiwanie gazu ze skał łupkowych, są USA, gdzie wydobycie sięga kilkuset miliardów metrów sześciennych rocznie. Prace poszukiwawcze przeprowadzano również w Meksyku, Australii, Rosji, a także w Europie, która jest jednym z najbardziej perspektywicznych obszarów pod względem obecności węglowodorów w złożach niekonwencjonalnych [26].

Na obszarze Polski zdecydowanie największe możliwości występowania gazu z formacji łupkowych stwierdzono w skałach dolnego paleozoiku na kratonie wschodnioeuropejskim, $\mathrm{w}$ basenie bałtyckim oraz $\mathrm{w}$ rejonie lubelskim [24, 26], co zaowocowało zainteresowaniem ze strony światowych oraz polskich koncernów sektora naftowego, jak m.in. Marathon Oil Company, San Leon Energy czy PGNiG.

Wielokrotnie podejmowano próby oszacowania wielkości tych potencjalnych zasobów. Oceny te jednak opierały się na niewielkiej ilości danych, często słabej jakości, jak na przykład bardzo optymistyczna ocena amerykańskiej instytucji EIA z 2011 roku [29, 31], według której na obszarze Polski miałoby się znajdować aż 5,3 bln $\mathrm{m}^{3}$ gazu w formacjach łupkowych, technicznie możliwego do wydobycia.

W 2012 roku oceny zasobów opartej na analizie rdzeni wiertniczych oraz danych geofizycznych podjął się Państwowy Instytut Geologiczny - Państwowy Instytut Badawczy (PIG - PIB). W swoim raporcie [23] podał, że zasoby gazu z łupkach $w$ basenach bałtyckim i podlasko-lubelskim mieszczą się w przedziale $348 \div 768 \mathrm{mld}^{3}$ i wystarczą na $35 \div 65$ lat pełnego zapotrzebowania polskiego rynku na gaz ziemny.

Kilka miesięcy po tej publikacji United States Geological Survey (USGS) wydał własny raport opierający się na podobnych założeniach i zestawie danych jak raport PIG - PIB. Podawane w nim potencjalne zasoby gazu technicznie możliwego do wydobycia są 10 razy mniejsze od obliczonych przez polskich naukowców i wynoszą około $38,1 \mathrm{mld} \mathrm{m}^{3}$ [29].

Mimo niepochlebnych opinii dotyczących raportów [22], krytyki działań rządu RP, prowadzących rzekomo do przeszacowania zasobów [28] oraz zachwiania optymistycznych nastrojów potencjalnych inwestorów [30], które doprowadziły do wstrzymania poszukiwań lub wycofania się z nich przez część inwestorów zagranicznych (m.in. Chevron, ExxonMobil), Polska w dalszym ciągu stoi przed dużą szansą rozwojową, jaką stwarza pozyskiwanie gazu ze skał łupkowych.

Korzyści, które niesie ze sobą wydobywanie gazu ze złóż niekonwencjonalnych (np. nowe miejsca pracy, wzrost niezależności energetycznej), skłaniają badaczy do poszukiwania złóż na coraz to nowszych obszarach naszego kraju. $\mathrm{Na}$ terenie Polski oprócz niewątpliwie najbardziej perspektywicznych basenów bałtyckiego i podlasko-lubelskiego znajdują się również inne obszary, na których obecne są skały ilasto-mułowcowe o wysokiej zawartości materii organicznej, mogące być potencjalnie skałami macierzysto-zbiornikowymi gazu ziemnego.

W niniejszym artykule oceniono bliżej obszar Górnośląskiego Zagłębia Węglowego (GZW), na którym mogą występować skały łupkowe zawierające gaz ziemny. Skoncentrowano się przy tym na serii mułowcowej, która ze względu na swoje specyficzne właściwości, jak m.in. wysoka zawartość materii organicznej i miąższość skał w swoim obrębie, wydaje się najbardziej obiecująca. Oceny dokonano, opierając się na analizie profili litologicznych z wybranych głębokich otworów wiertniczych wykonanych na zlecenie Państwowego Instytutu Geologicznego (numer pozwolenia na korzystanie $\mathrm{z}$ archiwalnych danych geologicznych: GIA-5502-1085/11). Lokalizacja wykorzystanych otworów została przedstawiona na rysunku 1 . Na tej podstawie podjęto próbę wyznaczenia interwałów głębokościowych o znacznym udziale skał iłowcowo-mułowcowych w profilu serii mułowcowej GZW.

\section{Charakterystyka geologiczna Górnośląskiego Zagłębia Węglowego}

Górnośląskie Zagłębie Węglowe, będące jednym z największych zagłębi węglowych Europy, stanowi przykład zapadliska przedgórskiego powstałego na przedpolu łuku fałdowego strefy śląsko-morawskiej, reprezentującego zespół pięter fałdowych waryscydów. Basen ten wykazuje szereg cech typowych dla fleksuralnego basenu przedgórskiego, wypełnionego osadami molasowymi, tworzącymi serie utworów produktywnych $[6,15]$.

Zapadlisko górnośląskie jest rozwinięte na skonsolidowanym cokole prekambryjskim zwanym masywem górnośląskim. Na nim spoczywają kolejno serie osadowe wyższych pięter $[4,5,15,17,18]$, w tym seria mułowcowa, 
podzielona na warstwy załęskie i orzeskie, obejmująca westfal A oraz dolną część westfalu B [27]. Charakterystyczna dla serii mułowcowej jest znaczna przewaga utworów drobnookruchowych (iłowców i mułowców) nad piaskowcami.
Podstawowe cechy skał iłowcowo-mułowcowych serii mułowcowej oraz - dla porównania - skał łupkowych na kratonie wschodnioeuropejskim oraz łupków Barnett w USA zostały opisane w tablicy 1.

\section{Metodyka}

Niniejsze opracowanie powstało na podstawie analizy kart otworowych wybranych głębokich otworów wiertniczych wykonanych na obszarze GZW na zlecenie PIG na przełomie lat siedemdziesiątych i osiemdziesiątych XX wieku w celu rozpoznania możliwie jak największej części profilu karbonu węglonośnego w obszarach perspektywicznych złóż węgla. Niektóre z tych otworów osiągnęły podłoże utworów karbońskich. Dodatkowo do analizy włączono profil otworu Dębieńsko-Głębokie 7, z uwagi na fakt, że w otworze tym obserwuje się największą miąższość serii mułowcowej [10]. W każdym z przyjętych do zestawienia profili 25 otworów poszukiwano odcinków skał iłowcowo-mułowcowych serii mułowcowej o miąższości nie mniejszej niż 30 metrów, niezawierających przerostów piaskowcowych. Założono, że miąższość ta, przy uwzględnieniu optymalności pozostałych parametrów, jest miąższością graniczną, poniżej której eksploatacja gazu z tego rodzaju skał jest nieopłacalna. Przyjęto również, że głębokość zalegania interesujących odcinków nie może być mniejsza niż 1000 metrów, ponieważ na mniejszej głębokości zbyt niskie ciśnienie hydrostatyczne mogłoby ułatwić ucieczkę gazu poza serię skalną.

Podczas analizy zwracano szczególną uwagę zarówno na ilość i rodzaj materiału organicznego występującego w tych skałach, jak i na obecność wkładek węgla humusowego. Założono, że wkładki węgla humusowego zawarte w odcinkach skał iłowcowo-mułowcowych mogą mieć miąższość nie większą niż 1 metr. Profile otworów, w których występują interesujące odcinki skał iłowcowo-mułowcowych, zostały przedstawione na rysunkach $2 \mathrm{a}$ i $2 \mathrm{~b}$.

Na podstawie powyższych danych i mapy autorstwa Jureczki i in. [10] przygotowano mapę (rysunek 1) ilustrującą położenie zestawionych otworów wiertniczych. Na mapie zostały wykreślone metodą interpolacji izolinie obrazujące sumaryczną miąższość perspektywicznych skał iłowcowomułowcowych na analizowanym obszarze. Otwory, w których nie znaleziono żadnego odcinka skał iłowcowo-mułowcowych o miąższości większej niż 30 metrów, oznaczono symbolem „<30".

\section{Dyskusja wyników}

Aby gaz ziemny mógł wytworzyć się w kompleksie skalnym, muszą zostać spełnione określone warunki. Potencjalnie gazonośna skała powinna charakteryzować się frakcją iłowcową lub mułowcową, która w odróżnieniu od frakcji większych utrudnia migrację gazu w skały otaczające. Omawiana skała powinna zawierać rozproszoną materię organiczną o III (gazotwórczym) typie kerogenu lub o innych typach, która w odpowiednich warunkach może zostać przekształcona w węglowodory (w tym w gaz ziemny). Gaz niepodlegający ekspulsji ze skały macierzystej zostaje w niej zamknięty. Skały iłowcowo-mułowcowe są więc dla gazu zarówno skałami macierzystymi, jak i zbiornikowymi.

Kompleks iłowcowo-mułowcowy GZW obejmuje z reguły iłowce, iłowce laminowane materiałem pylastym oraz mułowce $\mathrm{z}$ wkładkami piasku drobnoziarnistego. W skałach tych występuje liczna materia organiczna w postaci szczątków sigilarii, stigmarii, kalamitów, kordiatów, lepidofitów, paproci, a także detrytusu i sieczki roślinnej. Materia ta charakteryzuje się III typem kerogenu [14]. Omawiane skały zawierają również liczne pokłady węgla, miejscami o znacznej miąższości.
Podczas poszukiwań kompleksów łupków gazonośnych należy zwrócić uwagę na miąższość pakietów skał w badanym profilu oraz głębokość ich występowania. Głębokość ta determinuje zarówno opłacalność eksploatacji (im głębiej występują skały, tym mniejsza opłacalność), jak też skuteczność przeprowadzanych procesów szczelinujących.

Po przeanalizowaniu danych otworowych zidentyfikowano sześć otworów (rysunek 1), w których występuje 17 odcinków skał iłowcowo-mułowcowych spełniających powyższe założenia (zob. rozdz. Metodyka). Skały te znajdują się w zachodniej i południowo-zachodniej części GZW, a ich największa koncentracja przypada na południe od linii Gliwice-Mikołów-Tychy.

Otwory, w których odnotowano największą łączną miąższość interesujących odcinków, to: Dębieńsko-Głębokie 7 oraz Drogomyśl IG-1. W otworze Dębieńsko-Głębokie 7 występuje łącznie prawie 430 metrów skał iłowcowo-mułowcowych. Dwa odcinki tych skał mają miąższość znacznie przekraczającą 30 metrów (93,7 metra oraz 102,8 metra) (rysunek 2b).

W otworze Drogomyśl IG-1 znajdują się 3 interesujące odcinki, o łącznej miąższości prawie 160 metrów, z których 
jeden osiąga miąższość prawie 79 metrów (rysunek 2a). Należy jednak mieć na uwadze, że otwór ten jest zlokalizowany w obrębie erozyjnego wyniesienia morfologicznego utworów karbońskich, zwanego grzbietem Drogomyśla, co może mieć wpływ na ogólną miąższość serii mułowcowej, a zatem na udział pakietów iłowcowo-mułowcowych w jej profilu.

W pozostałych otworach (Woszczyce IG-1, Krzyżowice IG-1, Studzionka IG-1 i Chybie IG-1) 30-metrowe odcinki skał iłowcowo-mułowcowych osiągają sumarycznie znacznie mniejsze miąższości, mniejsze są również miąższości poszczególnych odcinków, wynoszące od 30 do 65 metrów.

W kierunku wschodnim od linii Gliwice-Pszczyna-Bielsko-Biała miąższość omawianych skał ulega znacznemu zmniejszeniu. Na pozostałych obszarach GZW nie odnotowano obecności odcinków skał iłowcowo-mułowcowych, które spełniałyby przyjęte założenia.

Niniejsza interpretacja dotyczy jedynie danych z głębokich otworów wiertniczych, wykonanych na zlecenie PIG, jednak z uwagi na fakt, że są one rozmieszczone równomiernie oraz że ich profile w znacznej większości przypadków obejmują całą serię mułowcową, uzyskane wyniki można uznać za miarodajne.

Można zatem stwierdzić, że na obszarze GZW występują odcinki skał frakcji iłowcowej i mułowcowej o optymalnej miąższości i głębokości zalegania, jednak łączna ilość perspektywicznych skał jest tam stosunkowo mała. Dla porównania sylurskie skały łupkowe na obszarze zachodniej części kratonu prekambryjskiego charakteryzują się zarówno zdecydowanie większą rozpiętością lateralną, jak i nieporównywanie większą miąższością (dochodzącą miejscami nawet do 1000 metrów) [26], co stawia je zdecydowanie wyżej w rankingu potencjalnych skał łupkowych akumulujących gaz ziemny w naszym kraju.

Przy poszukiwaniu skał łupkowych mogących zawierać niekonwencjonalne akumulacje gazu ziemnego należy zwrócić uwagę na zawartość substancji organicznej w tych skałach, opisywaną parametrem całkowitej zawartości węgla organicznego (TOC - total organic carbon). Przyjmuje się, że dolna granica wartości parametru TOC dla skał iłowcowo-mułowcowych zawierających shale gas wynosi $1 \div 2 \%$ wag. W niniejszych badaniach wykorzystano dane $\mathrm{z}$ analizy Rock Eval zamieszczone w artykule Kotarby i in. [13]. Należy jednak pamiętać, że dane TOC w ww. artykule dotyczą próbek pobieranych z pokładów węgla, a nie próbek materii organicznej z towarzyszących pokładom skał iłowcowo-mułowcowych. Przyjęto jednak założenie, że wartości TOC dla próbek z pokładów węgla nie będą w znaczący sposób różnić się od wartości TOC kopalnej materii organicznej zawartej w próbkach skał iłowcowo-mułowcowych.

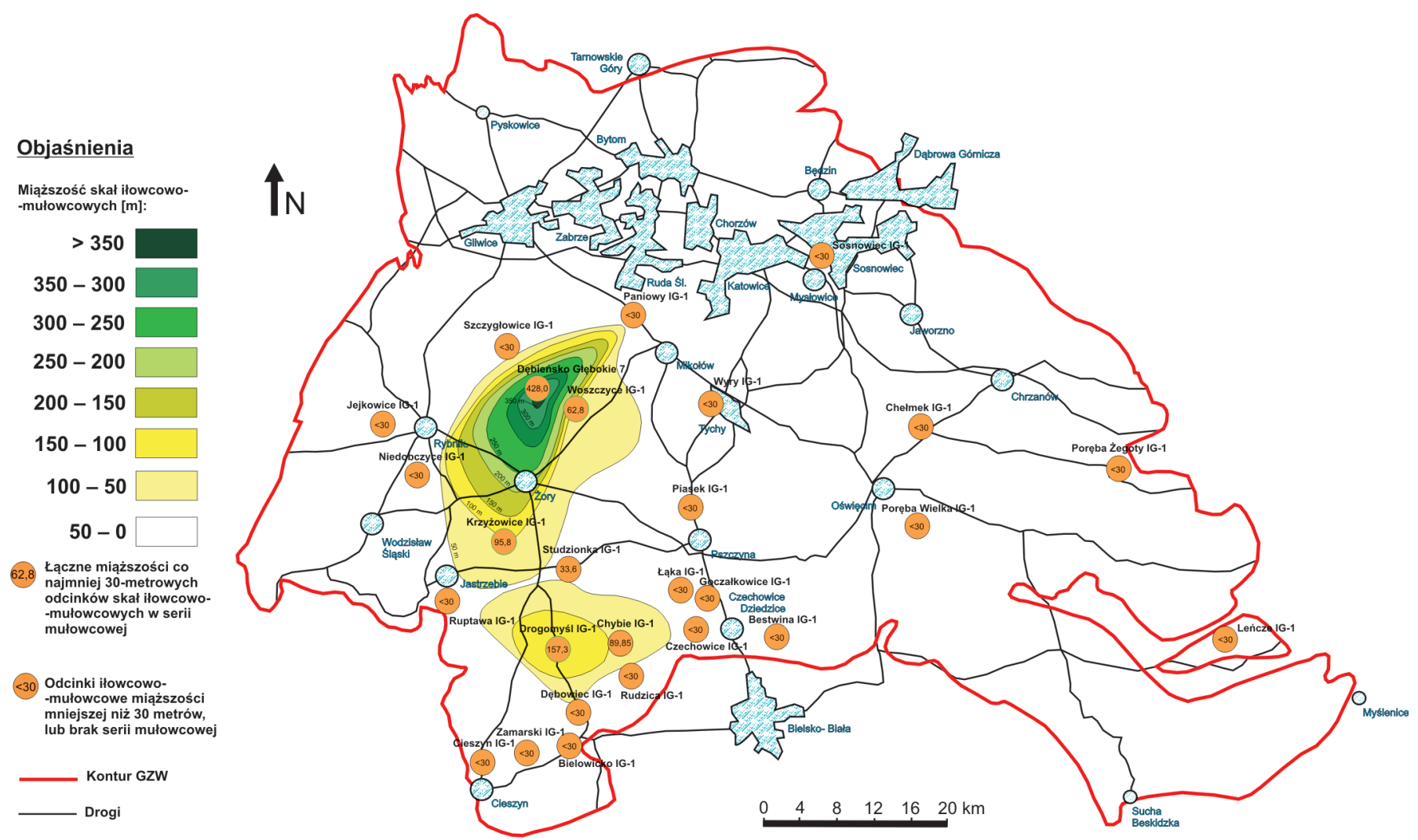

Rys. 1. Miąższość perspektywicznych skał iłowcowo-mułowcowych na terenie GZW. Izolinie wyznaczają obszary, na których występują perspektywiczne skały. Odcinki zalegają na głębokości poniżej 1000 metrów, mają miąższość co najmniej 30 metrów oraz charakteryzują się brakiem przerostów piaskowcowych i wkładek węgla humusowego o miąższości większej niż 1 metr 
Mimo że wartości parametru TOC wykazują duże zróżnicowanie nawet $\mathrm{w}$ obrębie skał serii mułowcowej z jednego interwału głębokościowego, to jego średnie wartości dla całego obszaru GZW pozostają na optymalnym poziomie, powyżej $1 \%$ wag. (średnio $2,3 \%$, tablica 1 ). Jednakże ze względu na małą liczbę danych (brak danych parametru TOC z próbek z kopalń leżących w zachodniej i południowo-zachodniej części GZW, gdzie występują największe nagromadzenia skał iłowcowo-mułowcowych) należałoby podejść do powyższych informacji z ostrożnością oraz podjąć próbę pozyskania i przeanalizowania danych z najbardziej perspektywicznych obszarów.

Do wytworzenia się gazu ziemnego w skałach iłowcowo-mułowcowych konieczna jest ich odpowiednia dojrzałość termiczna. Za optymalny przedział dojrzałości termicznej uznaje się zakres od 1,1\% do 3,5\% Ro (refleksyjności witrynitu). W niniejszych badaniach oparto się na danych refleksyjności witrynitu substancji węglowej [8] oraz materii organicznej zawartej w piaskowcach serii mułowcowej [1]. W obu przypadkach przyjęto założenie, że wartości dojrzałości termicznej materii organicznej zawartej w skałach iłowcowo-mułowcowych nie będą w dużym stopniu odbiegały od analogicznych wartości dojrzałości termicznej w towarzyszących im piaskowcach i pokładach węgla.

Na podstawie powyższych danych można stwierdzić, że pomimo iż dojrzałość termiczna serii mułowcowej ma tendencję wzrostową od wschodu w kierunku zachodnim, to jedynie bardzo niewielka część zachodniego obszaru GZW charakteryzuje się wymaganą dojrzałością termiczną, powyżej $1,1 \%$ Ro [8]. Analiza kopalnej materii organicznej zawartej w piaskowcach potwierdza niską dojrzałość termiczną omawianych skał. Jej wartości wahają się w granicach od $0,34 \%$ do $0,78 \%$ Ro [1], co oznacza, że w najbardziej perspektywicznych
A

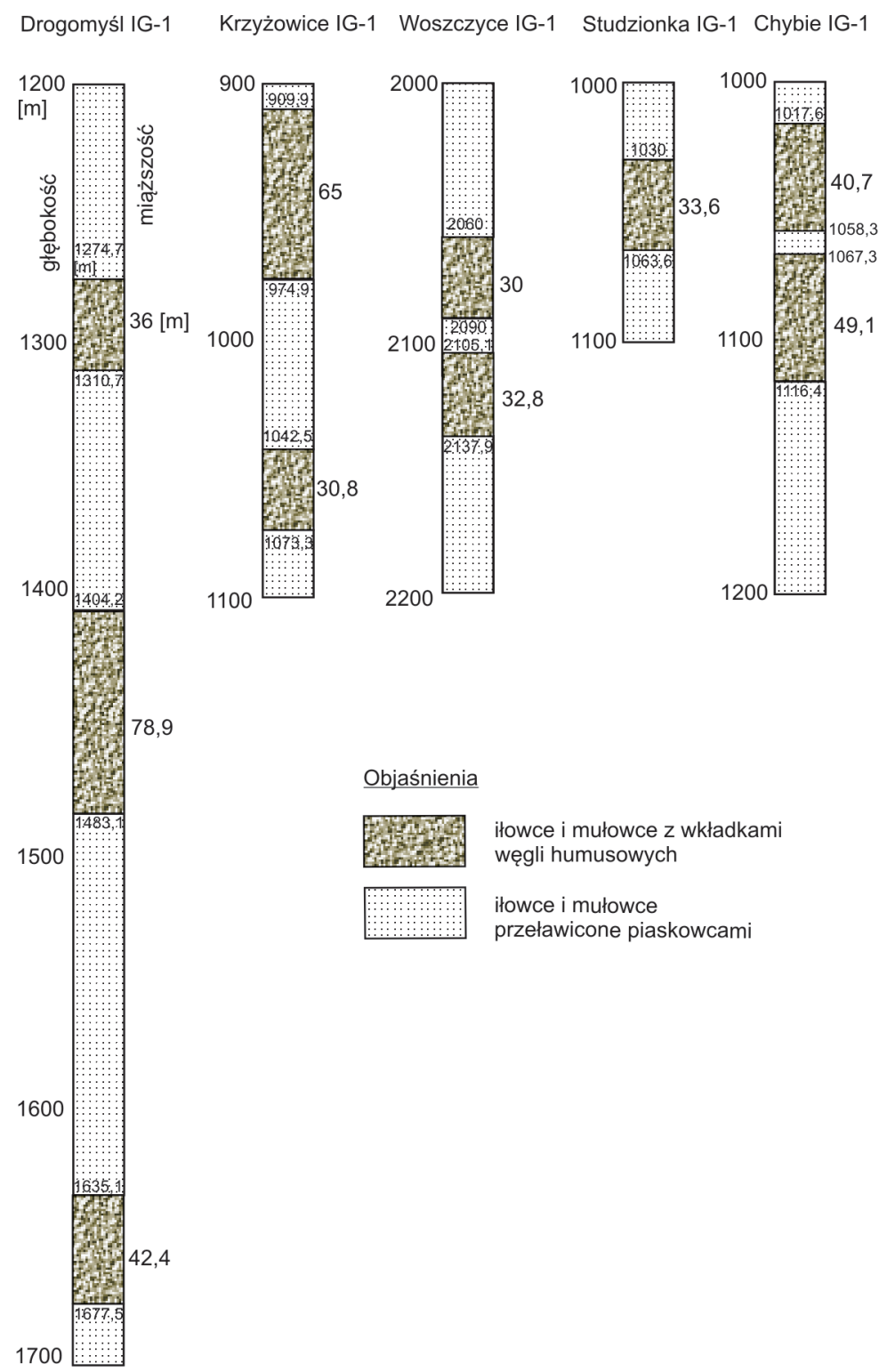

B

Dębieńsko DG-7

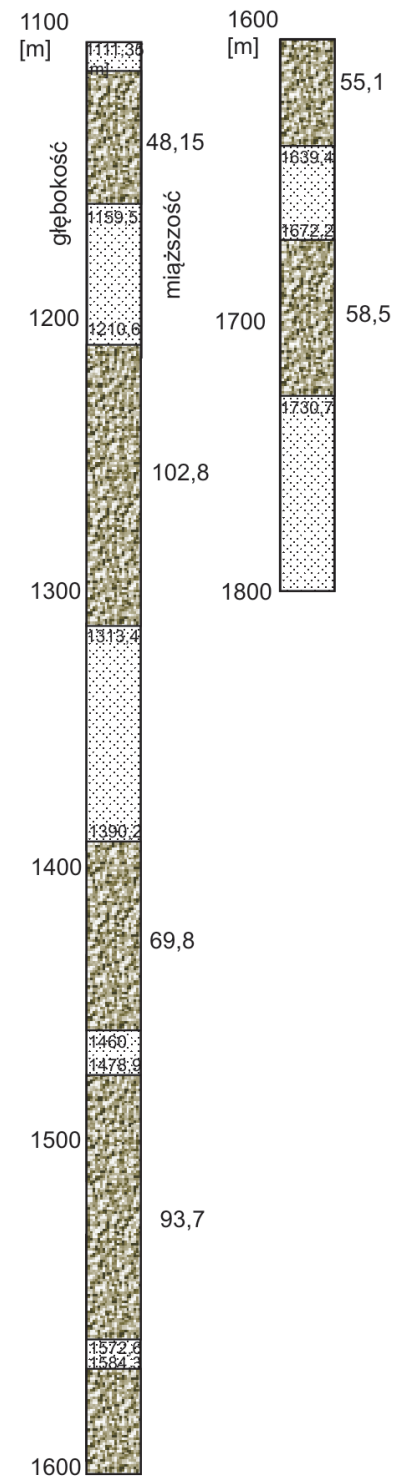

Rys. 2a, 2b. Profile otworów, w których występują co najmniej 30-metrowe odcinki skał iłowcowo-mułowcowych 
Tablica 1. Porównanie trzech kompleksów skalnych: łupków Barnett (Teksas, USA), łupków graptolitowych w basenach bałtyckim i lubelsko-podlaskim oraz skał iłowcowo-mułowcowych serii mułowcowej w GZW $[2,12,13,15,20,25,26,27]$

\begin{tabular}{|c|c|c|c|}
\hline & $\begin{array}{l}\text { Łupki Barnett w basenie } \\
\text { Fort Worth (Teksas, USA) }\end{array}$ & $\begin{array}{l}\text { Łupki graptolitowe dolnego } \\
\text { paleozoiku w basenach bałtyckim } \\
\text { i lubelsko-podlaskim }\end{array}$ & $\begin{array}{l}\text { Skały iłowcowo-mułowcowe serii } \\
\text { mułowcowej GZW }\end{array}$ \\
\hline Wiek & Dolny karbon, późny mississip & $\begin{array}{l}\text { Górny ordowik i dolny sylur } \\
\text { (najbardziej perspektywiczne - } \\
\text { łupki landoweru i wenloku) }\end{array}$ & $\begin{array}{c}\text { Karbon, westfal A i dolna część } \\
\text { westfalu B }\end{array}$ \\
\hline Miąższość & Od kilku do ok. $300 \mathrm{~m}$ & $\begin{array}{l}\text { Landoweru zazwyczaj } 20 \div 17 \mathrm{~m} \text {, do } \\
70 \mathrm{~m} \text {, wenloku silnie zmienna, od } \\
100 \mathrm{~m} \text { do } 1000 \mathrm{~m}\end{array}$ & $\begin{array}{l}\text { Zmienna, od } 100 \text { m na E do prawie } \\
2000 \text { m w okolicach Dębieńska }\end{array}$ \\
\hline $\begin{array}{l}\text { Głębokość } \\
\text { zalegania }\end{array}$ & Ok. $2000 \div 2600 \mathrm{~m}$ & $\begin{array}{l}<1500 \mathrm{~m} \text { na } \mathrm{E} \text {, do ponad } 5000 \mathrm{~m} \\
\text { na } \mathrm{W} \text {, średnio ok. } 2000 \div 3500 \mathrm{~m}\end{array}$ & $\begin{array}{l}\text { Stosunkowo płytka, od ok. } 300 \mathrm{~m} \\
\text { do ok. } 2100 \mathrm{~m}\end{array}$ \\
\hline $\begin{array}{l}\text { Wykształcenie } \\
\text { litologiczne }\end{array}$ & $\begin{array}{l}\text { Czarne łupki ropo- i gazonośne, } \\
\text { bogate w materię organiczną, } \\
\text { przeławicone piaskowcami } \\
\text { i podrzędnie dolomitami }\end{array}$ & $\begin{array}{l}\text { Iłowce i mułowce o wysokiej za- } \\
\text { wartości materii organicznej }\end{array}$ & $\begin{array}{l}\text { Głównie iłowce i mułowce. Udział } \\
\text { piaskowców do } 23 \% \text { miąższości se- } \\
\text { rii. Bogactwo flory i fauny, wysoka } \\
\text { węglozasobność }\end{array}$ \\
\hline Zawartość TOC & Średnio ok. 4\% wag. & $\begin{array}{l}\text { Lupki landoweru: od } 1,5 \% \text { do } \\
6 \% \text { wag., wenloku: od } 0,5 \% \text { do } \\
1,7 \% \text { wag. }\end{array}$ & Średnio ok. 2,3\% wag. \\
\hline Typ kerogenu & II & II & III \\
\hline $\begin{array}{l}\text { Dojrzałość } \\
\text { termiczna }\end{array}$ & Około $1,1 \div 1,4 \%$ Ro & Od $0,4 \%$ Ro na E, do $5 \%$ Ro na W & Od $0,5 \%$ Ro na E do $1,2 \%$ Ro na W \\
\hline $\begin{array}{l}\text { Tektonika i budowa } \\
\text { geologiczna }\end{array}$ & $\begin{array}{l}\text { Tektonika uskokowa, lokalnie } \\
\text { fałdy, obecne szczeliny krasowe }\end{array}$ & $\begin{array}{l}\text { Prosta, zwłaszcza basenu bałtyc- } \\
\text { kiego i obniżenia podlaskiego, nie- } \\
\text { co bardziej skomplikowana regionu } \\
\text { lubelskiego (tektonika blokowa) }\end{array}$ & $\begin{array}{c}\text { Skomplikowana, bloki tektoniczne } \\
\text { stosunkowo niewielkie, porozdzie- } \\
\text { lane licznymi uskokami }\end{array}$ \\
\hline $\begin{array}{l}\text { Geneza, } \\
\text { środowisko } \\
\text { depozycji }\end{array}$ & $\begin{array}{l}\text { Basen na przedpolu górotworu, } \\
\text { związany z późnopaleozoiczną } \\
\text { orogenezą Ouachita, kolizją } \\
\text { podczas formowania Pangei }\end{array}$ & $\begin{array}{l}\text { Sedymentacja drobnoklastyczna } \\
\text { związana z rozwojem subsydencji } \\
\text { basenów na zachodnim skłonie } \\
\text { kratonu wschodnioeuropejskiego, } \\
\text { spowodowana jego fleksuralnym } \\
\text { uginaniem w czasie kaledońskiej } \\
\text { kolizji Awalonii i Baltiki }\end{array}$ & $\begin{array}{l}\text { Limniczna, osady płaskiej doliny } \\
\text { aluwialnej formowanej przez } \\
\text { rzeki płaskodenne, meandrujące, } \\
\text { transportujące w przewadze } \\
\text { materiał drobnoziarnisty }\end{array}$ \\
\hline
\end{tabular}

obszarach GZW pod względem występowania potencjalnych skał gazonośnych oraz ich głębokości warunki paleotermiczne nie pozwoliły na wytworzenie gazu w skałach serii mułowcowej w znacznej ilości.

Niezależnie od tego gaz wytworzony w iłowcach i mułowcach w obrębie serii mułowcowej mógł być odprowadzany pakietami przepuszczalnych piaskowców występującymi $\mathrm{w}$ ich obrębie. Ponadto humusowa substancja organiczna reprezentująca III typ kerogenu obecna jest najczęściej w laminach bogatych w sieczkę roślinną.

Podczas rozpatrywania problemu pozyskiwania gazu $\mathrm{z}$ formacji łupkowych należy również uwzględnić budowę geologiczną obszaru, na którym zalegają analizowane skały macierzyste. Nawet gdy ilość gazu w łupkach w kompleksie skalnym jest bardzo duża, uwarunkowania geologiczne lub tektoniczne mogą uniemożliwić jego opłacalne wydobycie. Ogólnie przyjmuje się, że budowa geologiczna obszaru, z którego planuje się eksploatację gazu ziemnego, powinna być możliwie jak najmniej skomplikowana, a sama warstwa skalna zawierająca gaz powinna zalegać poziomo, gdyż takie ułożenie ułatwia wykonanie horyzontalnej części otworu wiertniczego. Warstwa taka powinna również charakteryzować się ciągłością i nie powinna być poprzecinana powierzchniami uskokowymi, które zmniejszają skuteczność hydraulicznego szczelinowania.

Niestety skomplikowana budowa geologiczna GZW, czyli zmienne kąty upadu warstw oraz stosunkowo gęsta sieć tektoniczna $[5,12]$, prawdopodobnie stwarzałaby bardzo duże problemy przy próbach wykonywania odwiertów kierunkowych oraz hydraulicznego szczelinowania.

Reasumując, seria mułowcowa GZW w kontekście poszukiwania gazu z łupków i rozważania opłacalności jego pozyskiwania przedstawia się jako obszar wysokiego ryzyka, co zobrazowane jest na rysunku 3. 


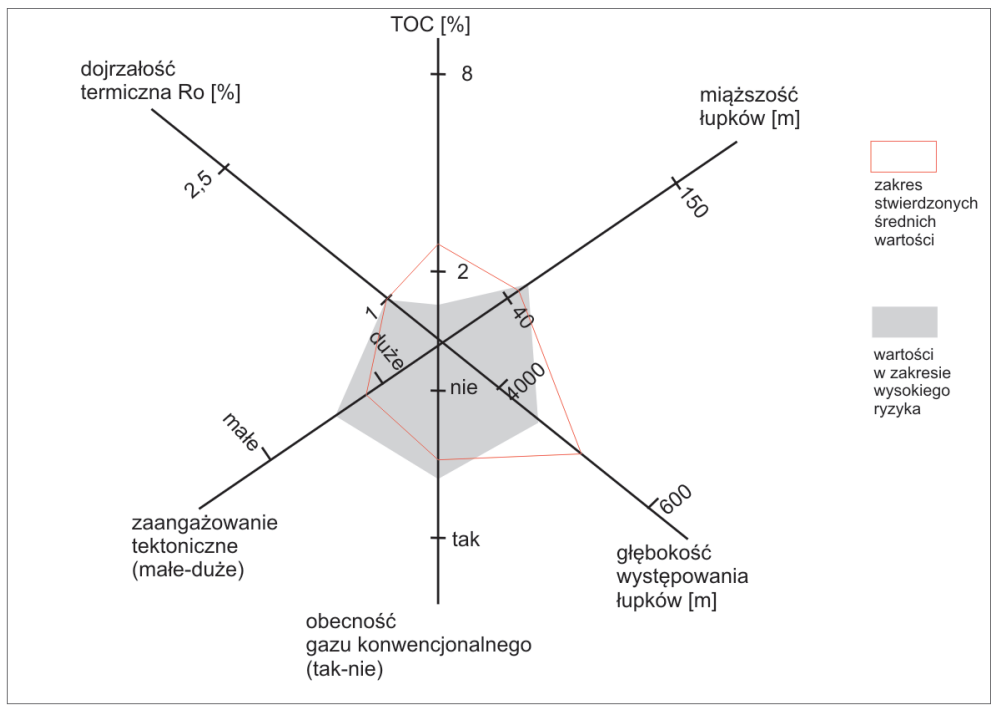

Rys. 3. Zakres ryzyka poszukiwawczego gazu z formacji łupkowych w serii mułowcowej na terenie GZW

\section{Podsumowanie}

Na obszarze zachodniej i południowo-zachodniej części Górnośląskiego Zagłębia Węglowego występują skały iłowcowo-mułowcowe serii mułowcowej, wykazujące szereg właściwości sprzyjających powstawaniu gazu ziemnego.

Są to skały zawierające materię organiczną charakteryzującą się III typem kerogenu oraz optymalnymi średnimi wartościami parametru TOC. Omawiane skały zalegają na odpowiedniej głębokości (poniżej 1000 metrów), jednak ich rozprzestrzenienie lateralne oraz miąższość na większości badanego obszaru są stosunkowo niewielkie (w porównaniu ze skałami łupkowymi ordowiku i syluru w basenie polskim i rejonie lubelskim).

W sześciu otworach wyznaczono 17 odcinków spełniających kryteria miąższości i głębokości zalegania pakietów iłowcowo-mułowcowych. Większość z tych pojedynczych odcinków ma miąższość rzędu 40 60 metrów, jedynie w otworach Dębieńsko-Głębokie 7 i Drogomyśl IG-1 zidentyfikowano pojedyncze odcinki o miąższości rzędu $80 \div 100$ metrów.

Dojrzałość termiczna omawianych skał, osiągająca na znacznym obszarze GZW wartości poniżej 1,1\% Ro, okazuje się jednak niewystarczająca, by w skałach tych mógł się wygenerować gaz ziemny w ilości gwarantującej opłacalność eksploatacji, a jeżeli nawet doszło do jego wytworzenia, to mógł on ulec migracji poprzez występujące wśród mułowców przepuszczalne pakiety piaskowcowe.

Dodając do powyższych argumentów fakt, iż GZW posiada skomplikowaną budowę geologiczną, mogącą znacząco utrudniać wykonywanie odwiertów kierunkowych oraz przeprowadzenie zabiegu hydraulicznego szczelinowania, można stwierdzić, że w skałach serii mułowcowej nie występują strefy, w których wszystkie powyższe parametry osiągałyby wartości upoważniające do podjęcia decyzji o rozpoczęciu poszukiwań gazu ziemnego w celu uruchomienia przemysłowej eksploatacji.

Prosimy cytować jako: Nafta-Gaz 2015, nr 10, s. 729-736

Artykuł nadesłano do Redakcji 20.05.2015 r. Zatwierdzono do druku 10.07.2015 r.

Artykuł powstał na podstawie pracy magisterskiej pt. Charakterystyka geologiczna serii mułowcowej w Górnoślaskim Zagłębiu Węglowym pod kątem możliwości występowania gazu tupkowego. Uniwersytet Śląski, 2012 [21].

\section{Literatura}

[1] Adamczyk Z.: Diageneza gazonosnych piaskowcow warstw orzeskich w KWK Silesia. Technika Poszukiwań Geologicznych, Geosynoptyka i Geotermia 2001, z. 4, s. 43-48.

[2] Bernard S., Wirth R., Schreiber A., Schulz H. M., Horsfield B.: Formation of nanoporous pyrobitumen residues during maturation of the Barnett Shale (Fort Worth Basin). International Journal of Coal Geology 2012, vol. 103, s. 3-11.

[3] Ciechanowska M., Matyasik I., Such P., Kasza P., Lubas J.: Uwarunkowania rozwoju wydobycia gazu z polskich formacji lupkowych. Nafta-Gaz 2013, nr 1, s. 7-17.

[4] Dembowski Z.: Krakowska seria piaskowcowa Gornoslaskiego
Zaglebia Weglowego. [W:] Karbon Gornoslaskiego Zaglebia Weglowego. Prace Instytutu Geologicznego 1972, t. 61, Warszawa, Wydawnictwa Geologiczne, s. 509-538.

[5] Dembowski Z.: Ogolne dane o Gornoslaskim Zaglebiu Weglowym. [W:] Karbon Gornoslaskiego Zaglebia Weglowego. Prace Instytutu Geologicznego 1972, t. 61, Warszawa, Wydawnictwa Geologiczne, s. 9-16.

[6] Gradzinski R., Doktor M., Kedzior A.: Sedymentacja osadow weglonosnej sukcesji Gornoslaskiego Zaglebia Weglowego: kierunki badan i aktualny stan wiedzy. Przegląd Geologiczny 2005, vol. 53, nr 9, s. 734-741. 
[7] Hadro J., Kedzior S.: Testowanie mozliwosci eksploatacji metanu pokladow wegla w Gornoslaskim Zaglebiu Weglowym otworami horyzontalnymi. [W:] Jureczka J. (red.): Wyzwania geologii regionu gornoslaskiego w XXI wieku. Materiały konferencyjne LXXXII Zjazdu Naukowego Polskiego Towarzystwa Geologicznego. Państwowy Instytut Geologiczny - Państwowy Instytut Badawczy, Warszawa 2013, s. 72.

[8] Jurczak-Drabek A.: Atlas petrograficzny zloz wegla kamiennego Gornoslaskiego Zaglebia Weglowego. Tablica 2b, Refleksyjnosc witrynitu $\left(R_{0}\right)$, seria mulowcowa, 1:300 000. Państwowy Instytut Geologiczny, Warszawa 1996.

[9] Jureczka J.: Perspektywy i problemy eksploatacji metanu z pokladow wegla $w$ warunkach zlozowych, gorniczych i srodowiskowych Gornoslaskiego Zaglebia Weglowego. [W:] Jureczka J. (red.): Wyzwania geologii regionu gornoslaskiego w XXI wieku. Materiały konferencyjne LXXXII Zjazdu Naukowego Polskiego Towarzystwa Geologicznego. Państwowy Instytut Geologiczny - Państwowy Instytut Badawczy, Warszawa 2013, s. 18-19.

[10] Jureczka J., Dopita M., Galka M., Krieger W., Kwarcinski J., Martinec P.: Zagospodarowanie gornicze i lokalizacja wiercen. [W:] Atlas geologiczno-zlozowy polskiej i czeskiej czesci Gornoslaskiego Zaglebia Weglowego. Warszawa 2005.

[11] Kedzior S.: Przystropowa strefa gazonosna w utworach karbonu poludniowej czesci Gornoslaskiego Zaglebia Weglowego - wystepowanie, parametry zbiornikowe wegla oraz możliwosci pozyskania metanu. Katowice, Wydawnictwo UŚ, 2012.

[12] Kedzior S., Hadro J., Kwarcinski J., Nagy S., Mlynarczyk M., Rostkowski R., Zalewska E.: Warunki naturalne wystepowania i metody eksploatacji metanu pokladow wegla w wybranych zaglebiach weglowych USA oraz mozliwosci rozwoju eksploatacji tego gazu w Polsce - sprawozdanie z wyjazdu szkoleniowego do USA. Przegląd Geologiczny 2007, vol. 55, nr 7, s. 565-570.

[13] Kotarba M., Kosakowski P., Botor D.: Modelowanie metoda GENEX i bilans generowania weglowodorow w kompleksie skal ilowcowo-mulowcowych utworow produktywnych gornego karbonu Gornoslaskiego Zaglebia Weglowego. [W:] Ney R., Kotarba M. (red.): Opracowanie modeli oraz bilansu generowania i akumulacji gazow w serii weglonosnej Gornoslaskiego Zaglebia Weglowego. Kraków, Wydawnictwo Centrum PPGSMiE PAN, 1995, s. 115-129.

[14] Kotarba M., Wieclaw D., Kosakowski P., Kowalski A.: Charakterystyka geochemiczna substancji organicznej utworow karbonu w poludniowej czesci bloku gornoslaskiego. [W:] Kotarba M. (red.): Mozliwosci generowania weglowodorow w skalach karbonu w poludniowej czesci bloku gornoslaskiego i malopolskiego. Rozdział 4. TBPŚ „Geosfera”, 2004, s. 49-70.

[15] Kotas A.: Gornoslaskie Zaglebie Weglowe. [W:] Osika R.: Budowa geologiczna Polski. T. VI. Zloza surowcow mineralnych. Warszawa, Wydawnictwa Geologiczne, 1987, s. 103-139.

[16] Kotas A.: Metan pokladow wegla Gornoslaskiego Zaglebia Weglowego. Mozliwosci zagospodarowania zasobow. Prace Państwowego Instytutu Geologicznego 1994, t. 142, Warszawa, s. 79-81.

[17] Kotas A., Malczyk W.: Gornoslaska seria piaskowcowa pietra namuru gornego Gornoslaskiego Zaglebia Weglowego. [W:] Karbon Gornoslaskiego Zaglebia Weglowego. Prace Instytutu
Geologicznego 1972, t. 61, Warszawa, Wydawnictwa Geologiczne, s. 427-466.

[18] Kotas A., Malczyk W.: Seria paraliczna pietra namuru dolnego Gornoslaskiego Zaglebia Weglowego. [W:] Karbon Gornoslaskiego Zaglebia Weglowego. Prace Instytutu Geologicznego 1972, t. 61, Warszawa, Wydawnictwa Geologiczne, s. 329-426.

[19] Matyasik I., Sloczynski T.: Niekonwencjonalne zloza gazu - shale gas. Nafta-Gaz 2010, nr 3, s. 167-177.

[20] Montgomery S., Jarvie D., Bowker K., Pollastro R.: Mississippian Barnett Shale, Fort Worth basin, north-central Texas: Gas-shale play with multi-trillion cubic foot potential. AAPG Bulletin 2005, vol. 89, no. 2, s. 155-175.

[21] Moska R.: Charakterystyka geologiczna serii mulowcowej w Gornoslaskim Zaglebiu Weglowym pod katem mozliwosci wystepowania gazu lupkowego. Praca magisterska, niepublikowana. Uniwersytet Śląski, 2012.

[22] Nawrocki J.: Skad ta roznica? Warszawa, Państwowy Instytut Geologiczny, 2012. http://www.pgi.gov.pl/pl/instytut-geologicznyaktualnosci-informacje/4314-dlaczego-rozbieżnosci.html (dostęp: 02.2015).

[23] Panstwowy Instytut Geologiczny - Panstwowy Instytut Badawczy: Ocena zasobow wydobywanych gazu ziemnego i ropy naftowej w formacjach lupkowych dolnego paleozoiku w Polsce (basen baltycko-podlasko-lubelski). Raport pierwszy. Warszawa 2012.

[24] Poprawa P.: Analiza osadow ilasto-mulowcowych w Polsce pod katem mozliwosci wystepowania w nich niekonwencjonalnych nagromadzen gazu ziemnego. Biuletyn Państwowego Instytutu Geologicznego - Państwowego Instytutu Badawczego 2010, nr 439, s. 159-172.

[25] Poprawa P.: Potencjal wystepowania zloz gazu ziemnego w lupkach dolnego paleozoiku w basenie baltyckim i lubelsko-podlaskim. Przegląd Geologiczny 2010, vol. 58, nr 3, s. 226-249.

[26] Poprawa P.: System weglowodorowy z gazem ziemnym w lupkach - polnocnoamerykanskie doswiadczenia i europejskie perspektywy. Przegląd Geologiczny 2010, vol. 58, nr 3, s. 216-225.

[27] Porzycki J.: Seria mulowcowa pietra westfalu dolnego Gornoslaskiego Zaglebia Weglowego. [W:] Karbon Gornoslaskiego Zaglebia Weglowego. Prace Instytutu Geologicznego 1972, t. 61, Warszawa, Wydawnictwa Geologiczne, s. 467-500.

[28] Pytel G.: Mniej gazu? Nie szkodzic Polsce! Rzeczpospolita 2012, 16 kwietnia.

[29] Rutkowski M.: Gaz pojawia się i znika, czyli krotka historia szacowania zasobow weglowodorow niekonwencjonalnych $w$ Polsce. Przegląd Geologiczny 2013, vol. 61, nr 6, s. 331-333.

[30] Talaga A.: Gazowej manny nie bedzie. Rzeczpospolita 2012, 23 marzec.

[31] United States Energy Information Administration: World shale gas resources: an initial assessment of 14 regions outside the United States. U.S. Washington 2011, 353 s. http://www.eia.gov/ analysis/studies/worldshalegas (dostęp: 02.2015).

[32] Zalewska E., Mlynarczyk M.: Metan pokladow wegla - cenny surowiec energetyczny czy zagrozenie dla srodowiska naturalnego i ludzi w Polsce. Przegląd Geologiczny 2003, vol. 51, nr 6, s. $465-468$.

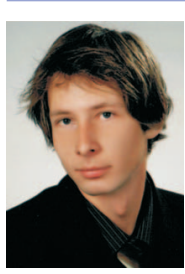

Mgr Rafał MOSKA

Inżynier Branżowy w Zakładzie Stymulacji Wydobycia Węglowodorów.

Instytut Nafty i Gazu - Państwowy Instytut Badawczy

ul. Lubicz $25 \mathrm{~A}$

31-503 Kraków

E-mail:moska@inig.pl
Dr hab. Sławomir KEDZIOR

Adiunkt na Wydziale Nauk o Ziemi Uniwersytetu

Śląskiego.

ul. Będzińska 60

41-200 Sosnowiec

E-mail: slawomir.kedzior@us.edu.pl 